\title{
Nicotine stomatitis in smokers: a case report
}

\author{
Doni MS. Prabowo*, Haris B. Widodo
}

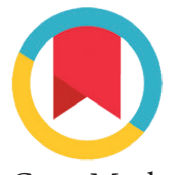

CrossMark

\section{Abstract}

Objective: The aim of this study is to describe and analyse nicotine stomatitis in smokers. Of the world population that consumes tobacco, Asia and Australia make up $57 \%$ of tobacco consumers. Tobacco can be consumed by various ways such as smoked tobacco, commonly known as cigarettes, or smokeless tobacco. Cigarettes are known to cause nicotine stomatitis in the oral cavity.

Methods: A 28-year-old man patient came with complaints of white spots on his hard palate. The patient has a medical history of asthma as a child and has been taking salbutamol. The patient has been smoking 3 packs of cigarettes a day since being 16 years old.

Results: Nicotine stomatitis that occurs on the hard palate appears as circular reddish shapes on the orifice of minor salivary glands. These lesions are formed from physically irritation caused by smoking. The lesions were benign and reversible.

Conclusion: Thought appropriate examination and treatment, these lesions were healed.
Department of Oral Biology Laboratory, Dental and Oral Hospital Jenderal Soedirman University, Purwokerto, Indonesia

*Corresponding to: Doni MS. Prabowo, Department of Oral Biology Laboratory, Dental and Oral Hospital Jenderal Soedirman University, Purwokerto, Indonesia spdonimardianto@gmail.com

Received: 25 January 2018 Revised: 19 March 2018 Accepted: 22 March 2018 Available online: 1 April 2018

Keywords: tobacco, smoked tobacco, nicotine stomatitis, benign lesions

Cite this Article: Prabowo DMS, Widodo HB. 2018. Nicotine Stomatitis in Smokers: a case report. Journal of Dentomaxillofacial Science 3(1): 58-60. D0I: $10.15562 / j \mathrm{dmfs} . v 3 i 1.708$

\section{Introduction}

According to the Tobacco Atlas, the percentage of the world population who consumed tobacco in 2009 was found to be $57 \%$ in Asia and Australia, $14 \%$ in Eastern Europe and the Soviet Union, $12 \%$ in the Americas, 9\% in Western Europe, and $8 \%$ the Middle East and Africa. Meanwhile, the Association of Southeast Asian Nations (ASEAN) is an area containing $10 \%$ of smokers from around the world and are responsible for $20 \%$ of global deaths caused by tobacco. The percentage smokers within the ASEAN countries is made up of $46 \%$ in Indonesia, $16 \%$ in the Philippines, $14 \%$ in Vietnam, 9\% in Myanmar, $8 \%$ in Thailand, 2\% in Malaysia, $2 \%$ in Cambodia, $1 \%$ in Laos, $0.4 \%$ in Singapore, and $0.04 \%$ in Brunei. ${ }^{1}$

Tobacco is one of the products of processed agricultural from the leaves of plants of the genus nicotiana. Smoked tobacco is consumed through cigarettes, cigars, or by the use of a pipe while smokeless tobacco is consumed by chewing tobacco leaves. Tobacco leaves are chewed in combination with the areca and maintained in the cavity of the mouth by placing it among the cheeks and gums. The use of chewed tobacco, with or without the areca, is mostly found in the villages of developing countries or used as a tradition in specific countries. $^{2}$

The influence of tobacco is generally associated with health but within the field of dentistry, tobacco is known to cause stained teeth that interfere with aesthetics and halitosis, known as bad breath. Ingredients in tobacco products and the burning of tobacco cause changes in the oral cavity such as dry mouth, raised intraoral temperature, changes in the oral cavity $\mathrm{pH}$, changes in immune response, and resistance against infection especially fungal infections and viruses. ${ }^{3}$

Smoking is also known to cause nicotine stomatitis in the oral cavity. Prevalence of nicotine stomatitis is very high in pipe smokers and reverse smokers. Lesions occur as a result of physical irritation caused by the smoke of a cigarette. ${ }^{4}$ The aim of this study is to describe and analyse nicotine stomatitis in smokers.

\section{Case Report}

On Thursday, November 7th 2017, a 28-year-old man came to the Dental Hospital Jenderal Soedirman University integration clinic with complaints of white spots on his hard palate. The white spots had been present for a long time but the patient had never got sick and had never been treated. The patient had a medical history in the form of asthma as a kid and routinely consumed salbutamol. The patient rarely suffers from a recurrence of asthma unless they're fatigued. The patient is also allergic to tungao. The patient had a treatment to fix an artificial tooth 1 month ago and is not suspected to have any systemic abnormalities. The patient is a entrepreneur that smokes 3 packs of cigarettes per day, often goes to sleep late, and suffers from alcoholism since the age of 16 years old.

An extraoral examination shows face symmetry, normal colouration, and no enlargement. The 


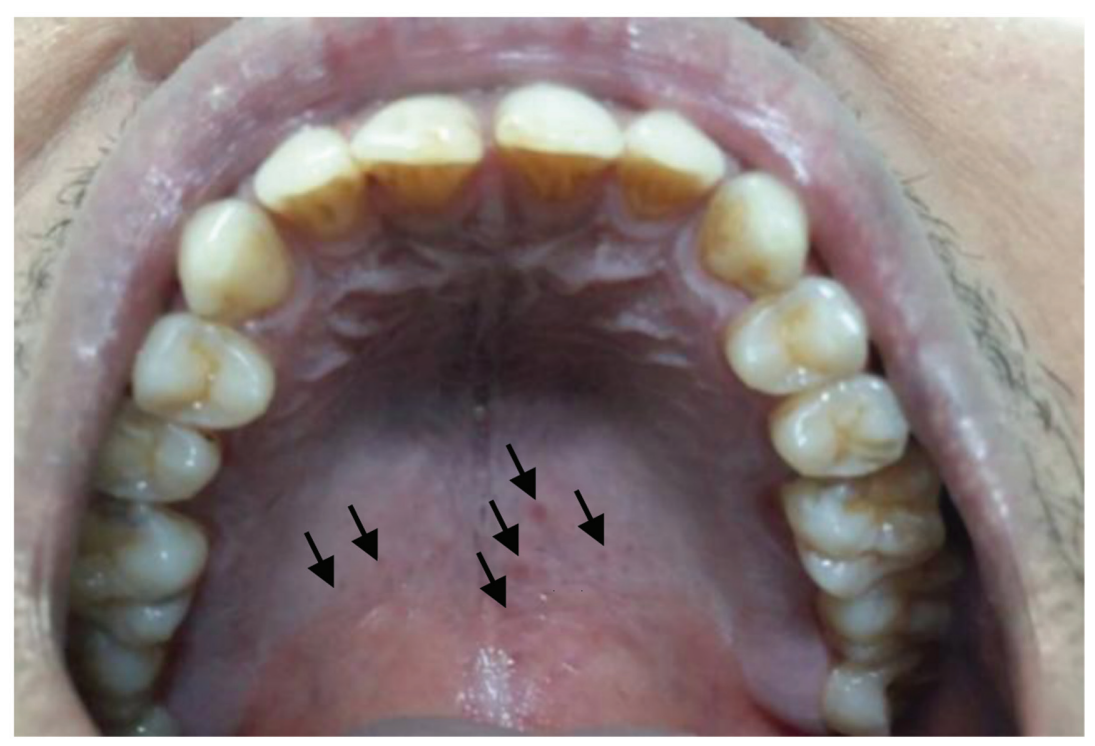

Figure 1 Nicotine stomatitis lesions on the hard palate marked by arrows (\)

patients eyes are positioned parallel and the eye colour is normal. The colour of the sclera is white and the colour of the eyelid is pink, therefore there is no suspected disorder. There is no enlargement observed in the neck. The hands, fingers, lymph node, and temporomandibular joint (TMJ) all appear normal. An intraoral examination showed lesions of papules in a globular shape and sized 1-2 $\mathrm{mm}$. There were multiple lesions appearing white with red spots in the middle. The lesions had a chewy consistency and could not be scraped off the hard palate. Nicotine stomatitis lesions on of the hard palate can be seen in figure 1 .

Nicotine stomatitis in patients it is not too serious and can be treated with palliative therapy. The patient has been educated to stop smoking and maintain a clean oral cavity.

\section{Discussion}

The prevalence of smoking in Indonesia is very high in various levels of society, especially in men, teenagers and adults. The smoking trend continues to rise from year to year in both men and women. Nicotine is extracted from tobacco in the process of smoking (inhaling) or chewing. Nicotine is attached to the organic acids found within the leaves of the native plant and if the leaves are dried slowly, the nicotine still remains. Alkaloids are stimulators that are also found in tobacco leaves and are responsible for the effects of cigarettes. Alkaloids are among many compounds found in tobacco leaves such as nicotine, anabasine, myosmine, and others. ${ }^{3}$

Nicotine is a toxic alkaloid compound that is contained in tobacco. When tobacco is extracted, nicotine is the main isolated compound, also known as 3-(1-methyl-2-pyrrolidinyl)pyridine, with the chemical formula $\mathrm{C}_{10} \mathrm{H}_{14} \mathrm{~N}_{2}$. In its pure state, nicotine is a volatile colourless liquid that is soluble in alcohols, ether and petroleum ether. It boils at $246-247^{\circ} \mathrm{C}$ and freezes at $80^{\circ} \mathrm{C}$. At low temperatures, nicotine emits an offensive odor but if heated, it will a produced vapour that interacts with the air and produces a colour change to become brown ${ }^{5}$

Nicotine is strongly alkaline but its neutral chemical structure allows it to pass through the nerve cell membrane. The toxicity of nicotine can cause nerve paralysis and can easily be absorbed through the skin. On average, tobacco contains $0.5-4 \%$ of nicotine. Nicotine produced in Indonesia usually contains $0.5-2.5 \%$ of nicotine. As the tobacco leaves mature, the percentage of nicotine decreases. The water level are high cause nicotine to leaves which have been preserved and processing the plant tend to be lacking. Reduced nicotine caused by the decomposition due to evaporation. Besides nicotine, tobacco also contains carbohydrates, chlorophyll, organic acids, enzymes, minerals, and metals. ${ }^{3}$

The most dangerous chemicals contained in cigarette smoke are tar, nicotine, and carbon monoxide. Tar, or sap tobacco, is a mixture of several hydrocarbon substances. Nicotine is the largest component of cigarette smoke and is an astringent additive. Carbon monoxide is a toxic gas that has a strong affinity to hemoglobin in red blood cells forming carboxyhemoglobin. Cigarette smoke also contains pyridine, ammonia, carbon dioxide, ketones, aldehydes, cadmium, nickel, zinc, and nitrogen oxides. At different levels, all substances are able to disturb the mucous membrane found in the mouth and respiratory tract. Cigarette smoke is acidic ( $\mathrm{pH}$ 5.5) and interacts with nicotine within the mucous cheeks to form of ions. ${ }^{6}$

Smoking can disrupt the normal lung function because hemoglobin interacts with carbon monoxide to form carboxyhemoglobin easier than oxygen. This causes the blood oxygenation of active smokers and passive smokers to be approximately $15 \%$ lower than normal oxygen levels. Diseases associated with tobacco are caused directly by smoking or exacerbated by smoking. The diseases that cause death in smokers are coronary heart disease, thrombosis of coronary, cancer and bronchitis. ${ }^{\text {? }}$

\section{Definition of nicotine stomatitis}

Nicotine stomatitis was discovered in 1941. Nicotine stomatitis was found in pipe smokers where the mucous was not covered by the denture. In 1958, the first example of nicotine stomatitis was found on the hard palate. It appeared as circular reddish lesions on the orifice of the minor salivary glands. The prevalence of nicotine stomatitis is very 
high for pipe smokers. Irritants from smoke come in direct contact with the palate mucous, especially on $2 / 3$ of the posterior hard palate. ${ }^{4}$

\section{Etiology of nicotine stomatitis}

Nicotine stomatitis is lesions that form due to the physical irritation from smoke. Temperatures at the burning end of a tobacco cigarette reach $650^{\circ} \mathrm{C}$ $\left(470^{\circ}-812^{\circ} \mathrm{C}\right)$ and the core temperature of cigarettes can reach $824^{\circ}-897^{\circ} \mathrm{C}$. During smoke inhalation, the oral cavity can reach $190^{\circ} \mathrm{C} .^{8}$ The high temperature smoke coming in direct contact with the palate mucous causes irritation and inflammation at the orifice of the minor salivary glands on hard palate. Microscopy has explained the changes in cells around the orifice of the minor salivary glands. Squamous cells on the wall of the salivary gland duct undergo hyperplasia and parakeratosis occurs on the orifice mucous. Microscopy explained that the lumen orifice minor salivary glands were not closed. ${ }^{8}$

Infiltration of inflammatory cells from blood vessels into intracellular space and accumulation of mast cells occurs in the subepithelial tissue. A comparison of histological results between a healthy hard palate and a hard palate with nicotine stomatitis showed that only nicotine stomatitis underwent histological changes. ${ }^{4}$

Histological changes of hard palate tissue only occurred in $2 / 3$ of the posterior hard palate. Nicotine stomatitis was not found on $1 / 3$ of the anterior hard palate and soft palate. This is due to a low distribution of minor salivary glands on $1 / 3$ of the anterior hard palate and soft palate. ${ }^{9}$

\section{Clinical manifestation of nicotine stomatitis}

Nicotine stomatitis presents as a red circular lesion around the orifice of the minor salivary glands on hard palate mucous. In addition, it is found also characterized by the thickening of the epithelium due to extended irritation on the palate mucous. ${ }^{8}$

\section{Treatment of nicotine stomatitis}

Nicotine stomatitis results in benign lesions and is reversible. Research by Walsh et al. ${ }^{4}$ explains that the hyperplasia around the orifice of the minor salivary glands will return to normal after two weeks without smoking. ${ }^{4}$

\section{Conclusion}

Smoking can cause various kinds of diseases and manifestations in the oral cavity, such as nicotine stomatitis. Appropriate examination and treatment can heal these lesions by quitting smoking for two weeks.

\section{Acknowlegment}

The author would like to thank the patient from his willingness to share this report.

\section{Conflict of Interest}

The authors report no conflict of interest.

\section{References}

1. Pusat Data dan Informasi, Kementerian Kesehatan RI, Hari Tanpa Tembakau Sedunia 31 Mei 2015.

2. Tumilisar DL. Tembakau dan pengaruhnya terhadap kesehatan mulut. J Kedokt Meditek 2011;17: 19-23.

3. Nururrahmah. Pengaruh rokok terhadap kesehatan dan pembentukan karakter manusia. Prosiding Seminar Nasional 2014;1: 78-84.

4. Walsh MW, Ellison JA. Treatment of tobacco use and dependence: the role of the dental professional. J Dent Educ 2005;69: 521-537.

5. Bardellini E, Amadori F, Conti G, et al. Oral mucousl lesions in electronic cigarettes consumers versus former smokers. Acta Odontol Scand 2017;21: 1-3.

6. Vellappally S, Fiala Z, Smejkalová J, et al. Smoking related systemic and oral diseases. Actamedica (Hradec Kralove) 2007;50: 161-166.

7. Musk AW, de-Klerk NH. History of tobacco and health. Respirology 2003;8: 286-290.

8. Sham ASK, Cheung LK, Jin LJ, et al. The effects of tobacco use on oral health. Hong Kong Med J 2003;9: 271-277.

9. Jones $\mathrm{KB}$, Jordan R. White lesions in the oral cavity: clinical presentation, diagnosis and treatment. Semin Cutan Med Surg 2015;34: 161-170.

10. Nurhasanah SH, Palmasari A, Setyaningtyas D, et al. Recurrent of aphthous stomatitis (RAS) and exfoliative cheilitis in elderly psoriasis sufferer. J Dentomaxillofac Sci 2016;1: 63-66.

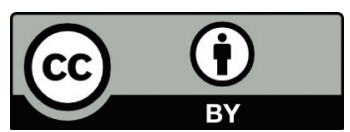

This work is licensed under a Creative Commons Attribution 